GOSPODARKA SUROWCAMI MINERALNYMI - MINERAL RESOURCES MANAGEMENT

\title{
Rare Earth Elements supply vs. clean energy technologies: new problems to be solve
}

\section{Introduction}

In recent years, many countries and businesses have made the low-carbon, green, and sustainable economy a high priority. China and the US pledged to cut greenhouse gas emissions in 2014, arousing further enthusiasm for this concept. The reasons for this priority range from increasing concerns over global environmental problems (e.g., global warming, ozone depletion) and the sustainable development of human beings, to the reduction of traditional energy and the rising cost of mineral resources. Clean energy technologies such as hybrid electric vehicles (HEVs), wind energy, and high-efficiency lighting are becoming a new growth point in the world economy under the influence of this concept. However, there is a significant obstacle to these industries: rare earth elements (REEs) (Dutta et al. 2016; Golev et al. 2014; Stegen 2015).

REEs are a group of 15 lanthanides plus yttrium and scandium (see Table 1). They can be divided into two groups-light rare earth elements (LREEs) and heavy rare earth elements (HREEs)-according to atomic weight. Scandium is not regarded as a LREE or HREE, as it is not produced from the same deposits as other REEs (USGS, 2014a), and promethium is a radioactive element, which does not occur in nature. Table 1 shows the average distribution

* Ph.D., Department of Mineral Resources Engineering University of Science and Thechnology Beijing, Beijing, China; e-mail: blz1985@163.com

** Professor, Department of Mineral Resources Engineering University of Science and Thechnology Beijing, Beijing, China; e-mail: zxli@ustb.edu.cn

*** BA, Department of Mineral Resources Engineering University of Science and Thechnology Beijing, Beijing, China 
Table 1. Average distribution of REEs across 51 deposits

Tabela 1. Średni rozkład poszczególnych pierwiastków ziem rzadkich w 51 złożach

\begin{tabular}{|c|c|c|c|c|}
\hline REE & Symbol & Atomic number & Category & Average distribution \\
\hline Lanthanum & $\mathrm{La}$ & 57 & LREE & $24.9 \%$ \\
\hline Cerium & $\mathrm{Ce}$ & 58 & LREE & $43.2 \%$ \\
\hline Praseodymium & $\operatorname{Pr}$ & 59 & LREE & $4.6 \%$ \\
\hline Neodymium & $\mathrm{Nd}$ & 60 & LREE & $16.2 \%$ \\
\hline Promethium & $\mathrm{Pm}$ & 61 & LREE & Does not occur in nature \\
\hline Samarium & $\mathrm{Sm}$ & 62 & LREE & $2.2 \%$ \\
\hline Europium & $\mathrm{Eu}$ & 63 & HREE & $0.3 \%$ \\
\hline Gadolinium & $\mathrm{Gd}$ & 64 & HREE & $1.4 \%$ \\
\hline Terbium & $\mathrm{Tb}$ & 65 & HREE & $0.2 \%$ \\
\hline Dysprosium & Dy & 66 & HREE & $0.9 \%$ \\
\hline Holmium & Ho & 67 & HREE & $0.2 \%$ \\
\hline Erbium & Er & 68 & HREE & $0.5 \%$ \\
\hline Thulium & $\mathrm{Tm}$ & 69 & HREE & $0.1 \%$ \\
\hline Ytterbium & $\mathrm{Yb}$ & 70 & HREE & $0.4 \%$ \\
\hline Lutetium & $\mathrm{Lu}$ & 71 & HREE & $0.1 \%$ \\
\hline Yttrium & $\mathrm{Y}$ & 39 & HREE & $4.9 \%$ \\
\hline
\end{tabular}

Source: EC 2016.

of individual REEs across 51 deposits across the world. Cerium is the most naturally abundant, followed by lanthanum; thulium and lutetium are the least abundant. LREEs are generally more abundant than HREEs (EC 2016).

Owing to their unique magnetic, optical, and catalytic properties, REEs can be used in a wide variety of products and technologies, including computing and defense systems and clean energy technologies (Golev et al. 2014; Gupta and Krishnamurthy 2005). They are particularly important for luminescent materials and permanent magnets, which are widely used in wind turbines, HEVs, all-electric vehicles, light-emitting diodes, and fluorescent lamps (US DoE 2011). The annual growth rate of global REE demand is expected to increase by $5 \%$ by 2020 (Dutta et al. 2016). Moreover, the demand for $\mathrm{Nd}$ and Dy is expected to rise by $700 \%$ and $2600 \%$ respectively in the next 25 years (Alonso et al. 2012). Therefore, a stable REE supply chain is indispensable to the development of clean energy technologies.

The source of most REEs is China, which has abundant REE reserves and advanced processing technologies (Chen 2011; Hurst 2010). The world has been heavily dependent on 
China's REE supply since 2000 (Wübbeke 2013). In 2010, however, China sharply cut export quotas on REEs by almost $40 \%$ over the 2009 rate, which drove REE prices to very high levels between the end of 2010 and mid-2011 and caused shortages of some REEs (Zhang et al. 2015). Countries and businesses all over the world realized that the REE supply chain was vulnerable and that the development of clean energy technologies would face a shortage of raw materials. This paper aims to provide an overall understanding of REEs and clean energy technologies, highlight the imbalance between REE supply and demand, and propose alternatives and measures for overcoming this imbalance, while also discussing the challenges these measures face.

\section{REEs and clean energy technologies}

REEs play an important role in petroleum refining, high-efficiency lighting, and hybrid electric vehicles, which in turn are important for energy conservation, developing a low-carbon economy, and reducing carbon emissions. REE production and consumption are typically expressed in terms of rare earth oxide (REO). Global REE consumption was 113,250 tons REO in 2012, and the percentage of consumption for magnets, batteries, phosphors, and catalysts out of total consumption was $20 \%, 8 \%, 7 \%$, and $20 \%$ respectively (EC 2016). Table 2 shows the main usages of REEs and their percentages of total consumption (EC 2016; US DoE 2011).

$\mathrm{La}$ and $\mathrm{Ce}$ can be used in auto catalysts and as additives for fluid catalytic cracking; they transform heavy molecules into lighter compounds, increase gasoline output, and reduce emissions caused by refining (US DoE 2011). REEs are also essential to catalytic converters in cars, enabling them to run at high temperatures, and increasing their effectiveness and decreasing costs by reducing the amount of platinum and other precious metals required (BGS 2010).

REEs can emit light in the visible range due to their special chemical and physical properties; thus they play an important role in high-efficiency lighting, mainly for compact fluorescent bulbs (CFLs) and light-emitting diode bulbs (LEDs) (Machacek et al. 2015; Wilburn 2012). CFLs are about four times more efficient than the equivalent energy of incandescent light bulbs, while LEDs are about $20 \%$ more efficient than CFLs and have a longer service life (Machacek et al. 2015). The global LED market is estimated to total USD 94 billion by 2020 , representing approximately $60 \%$ of the global lighting market.

Neodymium iron boron $(\mathrm{NdFeB})$ permanent magnets (PMs) constitute a very important component in wind turbines, HEVs, and all-electric vehicles (AEVs). NdFeB magnets were developed in the mid-1980s and have now largely replaced samarium-cobalt (SmCo) magnets (Du and Graedel 2011; Gupta and Krishnamurthy 2005; Stegen 2015). With the global development of wind energy, wind generators are using larger and more powerful turbines, which are more likely to use $\mathrm{NdFeB}$ magnets, as they can dramatically reduce the size and weight of the generator compared to non-PM design generators. For the same reasons, 
Table 2. Summary of REE usage

Tabela 2. Zestawienie kierunków wykorzystania REE

\begin{tabular}{|c|c|c|}
\hline REE & Main use & Percentage \\
\hline $\mathrm{Sc}$ & Aerospace framework, special alloy, neutron generator & NA \\
\hline Y & Television and computer screen, CFLs, and LED lights & 6.8 \\
\hline $\mathrm{La}$ & Petroleum cracking and catalyst, camera lenses, battery electrodes & 27.8 \\
\hline $\mathrm{Ce}$ & Catalytic converters, metal production, refining crude oils & 40.2 \\
\hline $\operatorname{Pr}$ & Permanent magnets, glass and ceramics colorant, lasers & 4.4 \\
\hline $\mathrm{Nd}$ & Permanent magnets, metal production improver & 17.6 \\
\hline Pm & Isotope luminescent materials & NA \\
\hline $\mathrm{Sm}$ & Sm-co permanent magnet, $\mathrm{X}$-ray lasers & 0.5 \\
\hline $\mathrm{Eu}$ & Color television screens, LED lights, $X$ ray intensifying screens & 0.4 \\
\hline Gd & Magnetic refrigeration, metal production, optical glass & 0.9 \\
\hline $\mathrm{Tb}$ & Permanent magnet additive, giant magnetostrictive material & 0.2 \\
\hline Dy & Permanent magnet additive, luminescent material & 0.7 \\
\hline Ho & Laser glass, glass coloring, metal halide lamp, dielectric ceramic & \multirow{5}{*}{0.5} \\
\hline Er & Signal amplification in fiber optic cables, laser glass & \\
\hline $\mathrm{Tm}$ & Fiber amplifier, laser glass & \\
\hline $\mathrm{Yb}$ & Laser glass, fiber amplifier & \\
\hline $\mathrm{Lu}$ & Medical isotope radiation therapy & \\
\hline
\end{tabular}

NA: not available.

NdFeB magnets dominate the EV and HEV markets; almost all mass-produced HEVs and EVs use rare earths PMs in their motors, because the motors are constrained in size and weight in order to fit within existing design parameters (US DoE 2011). Smaller amounts of HREEs and other metals are sometimes added to $\mathrm{NdFeB}$ magnets to fine tune their characteristics. The most important additive is dysprosium, which can help NdFeB magnets increase the value of intrinsic coercivity and resistance to demagnetization, thus allowing the NdFeB magnets to be used at higher temperatures (BGS 2010).

Meanwhile, a magnetic refrigeration method dependent on REEs is being developed, which will be more energy-efficient than the standard refrigeration method. Solid oxide fuel cells are a promising clean energy technology for electrochemically generating electricity using REEs. Many other clean technologies based on REEs are being researched, such as gas turbines, water treatment, and grid storage batteries (US DoE 2011). 
The European Commission considers REEs as critical raw materials with high supply risks for European green industries (EC 2014). The British Geologic Survey Risk List (BGS 2016) has listed REEs as its top at-risk marketable element. The US Department of Energy has identified five critical REEs in terms of their importance and the severity of their supply risk: Dy, Nd, Eu, Y, and Tb (US DoE 2011). Nd is the main component of the NdFeB magnet. The rising demand for clean energy technologies has produced a corresponding increase in demand for $\mathrm{Nd}$. Its production is unlikely to keep pace with demand, although it is a light rare earth element and is much more abundant than HREEs. Dy is used mainly in NdFeB magnets as an additive. Tb, Y, and Eu are used mainly in effective lighting.

\section{Supply and demand of REEs}

\subsection{Supply of REEs}

REEs were first produced commercially in Sweden and Norway in the $1880 \mathrm{~s}$, followed by Brazil, India, and the US. They were not very productive until the 1960s. Figure 1 shows global REE production from 1900 to 2015. Prior to 1965, there was little demand for REEs, and most were produced in India, Brazil, Australia, and South Africa (USGS 2014b).

The demand for REEs stepped into its first fast-growth stage in the mid-1960s, as the first color television sets were entering the market. In 1966, the US became the global leading REE producer, with most of the production originating from the Mountain Pass mine in California. Since 1985, however, US production has gradually decreased as a result of China's REEs production. The Mountain Pass mine was closed in 2002.

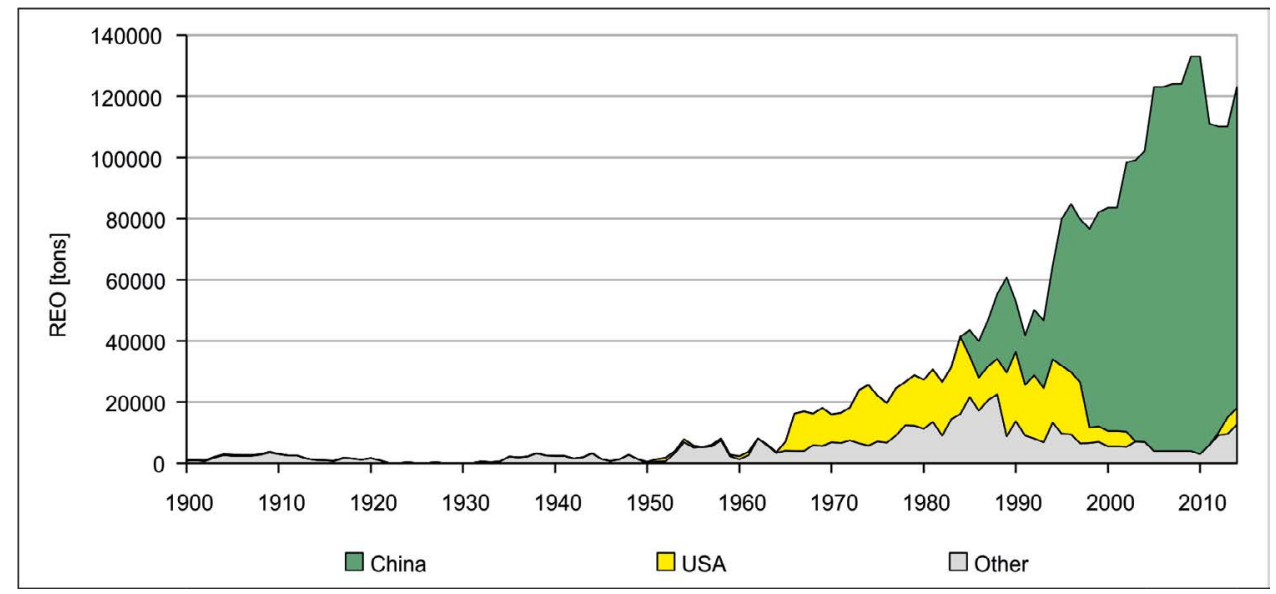

Fig. 1. Global REE production from 1900 to 2015 (REO, tons) Source: USGS 2014b 
China entered the global REE market in the late 1970s (SCIO 2012). From 1985 to 1998, the Chinese government encouraged REE production through a tax rebate policy (Han et al. 2015), and China gradually became the world leading REE producer in the early 1990s. China steadily increased its output from 1995 to 2002 and sold REEs at such low prices that Mountain Pass and other mines around the world were unable to profit from REE production. From 2000 to 2011, China had a monopoly of the world REE supply (Rollat et al. 2016; Wübbeke 2013); it accounted for an average of $93 \%$ of world production, reaching its highest share in 2010 (97\% of global REE production) (USGS 2010).

China's share of global REE reserves does not match its production share. According to USGS data (USGS 2016), global REE reserves are estimated at 130 million tons REO, located in China (55 million tons), Brazil (22 million tons), Australia (3.2 million tons), India (3.1 million tons), the US (1.8 million tons), and other countries such as Russia, Malaysia, Thailand, and Vietnam (a total of 41 million tons). China's share of global reserves is about $42 \%$, far below its share of global output $(85 \%)$. There are many reasons for this, including the support of the Chinese government for its REE industry, as well as low labor costs and a flexible environmental regulatory framework (UNCTAD 2014). These factors have allowed China to produce REEs at a lower cost than other producers; other countries found that it was cheaper to import REEs from China than to produce them domestically, and thus reduced or ceased production.

\subsection{Demand for REEs}

In 1953, global REE demand was approximately 1,000 tons REO, with a market value of USD 25 million. This rose significantly, to 66,000 tons in 1997, and reached about 125,000 tons in 2008, with a market value of USD 1.5 to 2 billion (Kingsnorth 2013). Afterwards, REE demand fell slightly due to the economic crisis of 2008 and the high prices from the end of 2010 to mid-2011. According to Roskill, global demand for REEs in 2014 was 118,000 tons REO and will increase to about 170,000 tons by 2020 (an increase of about $5 \%$ per year) (Rollat et al. 2016). The global market based on REE products is evaluated to be worth USD 1.5 to 2 trillion (Tukker 2014).

China represents $85 \%$ of global REE production (USGS 2016); this market monopoly is harmful because even small changes in this system, such as Chinese export quotas on REEs (see Table 3), could lead to huge instabilities in the global REE supply chain. A change in China's REE policy would be particularly disruptive. China has begun to combat smuggling and has closed several small mines in its southern provinces, reducing the availability of REEs in the global market, especially HREEs (ERECON 2014; Mancheri 2015). There is an urgent need to develop and facilitate innovative ways of providing a more stable supply chain. 
Table 3. China's export quotas for REEs from 2005 to 2014 (REO, tons)

Tabela 3. Chińskie kwoty eksportowe dla REE w latach 2005-2014 [t]

\begin{tabular}{|c|c|c|c|r|}
\hline Year & Export quota & Change & ROW & Surplus \\
\hline 2005 & 65,609 & $0.0 \%$ & 48,000 & 17,609 \\
\hline 2006 & 61,821 & $-6.0 \%$ & 53,000 & 8,821 \\
\hline 2007 & 59,643 & $-4.0 \%$ & 55,000 & 4,646 \\
\hline 2008 & 56,939 & $-4.5 \%$ & 54,000 & 2,939 \\
\hline 2009 & 50,145 & $-12.0 \%$ & 25,000 & 25,145 \\
\hline 2010 & 30,259 & $-40.0 \%$ & 53,000 & $-22,742$ \\
\hline 2011 & 30,184 & $-0.0 \%$ & 35,000 & $-4,816$ \\
\hline 2012 & 30,996 & $+0.0 \%$ & 41,000 & $-10,004$ \\
\hline 2013 & 31,001 & $+0.0 \%$ & 40,000 & $-8,999$ \\
\hline 2014 & 30,610 & $-0.0 \%$ & 45,000 & $-14,390$ \\
\hline
\end{tabular}

ROW: rest of world.

Source: author's adaptation of Kingsnorth (2013), Ministry of Land and Resources of PRC.

\section{Enhancing the REE supply chain}

Enhancing the REE supply chain calls for new solutions, including exploring new REE projects, reopening old REE mines, developing efficient recycling and substitution techniques, and reducing critical REE content in end-use products in order to ensure the stability of the supply chain for clean energy industries (Alonso et al. 2012; EC 2016).

\subsection{Exploring the REE projects}

REEs are actually not rare in the earth's crust; about 200 rare earth minerals (e.g., carbonates, borates, oxides, hydrates) are widely distributed in the world, especially in China, the Commonwealth of Independent States, Brazil, Australia, India, and Malaysia (Kanazawa and Kamitani 2006). However, REEs occurring in geological deposits are usually associated with other elements, sometimes radioactive elements, making the extraction of REEs challenging and expensive.

Australia and the US have been two important REE suppliers. Before the 1990s, the Mountain Pass mine in California represented $60 \%$ of the world's REE production. In the early 1990s, Australia stopped REEs production, and the Mountain Pass mine closed in 2002, due mainly to environmental problems (MEP 2009; BGS 2010) and its inability 
to compete with China's lower-priced REEs. China had not only lower labor costs but a flexible environmental regulatory framework as well; several of China's REE deposits also have mining cost advantages. Through these advantages, China quickly became the world's leading REE producer (UNCTAD 2014).

The world's heavy dependence on China's REE production and the REE supply chain remained basically unchanged for 20 years. This changed abruptly in 2005, when China gradually reduced its annual export quotas on REEs, causing dramatic price hikes and shortages of some REEs in 2010 and 2011. The global REE supply chain faced the risk of disruption. The high REE prices made investors and companies interested in exploring REE deposits. Mt. Weld in Australia, Mountain Pass in the US, Kvanefjeld in Greenland, and Zandkopsdrift in South Africa have the potential to become global REE suppliers over the coming years.

Mt. Weld in Australia, owned by Lynas Corporation, has four deposits: the Central Lanthanide Deposit (CLD), Duncan, Crown, and Swan deposits. CLD is one of the highest-grade REE deposits in the world. The reserves in Mt. Weld represent more than 25 years of continuous operation based on the production of 22,000 tons REO per year (Lynas 2015). In 2010, Lynas signed a strategic alliance agreement with the Sojitz Corporation and received investment funds from Sojitz and the Japan Oil, Gas and Metals Notional Corporation. In 2011, Lynas obtained a license to operate the Mount Weld Concentration Plant and, in 2012, received a temporary operating license for the Lynas Advanced Material Plant (Lynas 2012), a processing center for REEs located at the Kuantan in Malaysia. The capacity level in Phase 1 is 11,000 tons REO per year until market prices recover, and its ultimate production capacity is 22,000 tons per year.

The Mountain Pass in California began operations in 1952 and was owned by the Molybdenum Corporation of America. From 1977 to 1998, the mine continued to produce REO for the Unocal Corporation. In 1998, due to leaks in a wastewater pipeline, most REEs separation operations were suspended. Ultimately, the mine stopped production in 2002 because of softening REE prices. It was acquired by the Chevron Corporation in 2005 . In 2008, Molycorp acquired the Mountain Pass, and reopened it in 2012. It was capable of producing 19,050 tons of REO per year (Molycorp 2013); however, it closed in 2015 due to Molycorp's bankruptcy.

Kvanefjeld is the most famous deposit in Greenland. It was discovered in the 1950s and is now owned by Greenland Minerals and Energy. It has a vast multi-element resource that includes REEs, uranium, and zinc. Its latest resource estimate (March 2011) includes 6.6 million tons of total REO (including 0.25 million tons of heavy REO). South Africa's Zandkopsdrift deposit is probably one of the world's most rapidly developed projects. Its 2014 reserve estimate includes 0.7887 million tons of REO, and its preliminary feasibility study published in 2015 shows that separating REEs is both technically feasible and economically robust.

In addition, a search for new REE deposits is being driven by governments and businesses. New REE deposits and projects have been explored in Australia, Brazil, Canada, China, 
Greenland, Kyrgyzstan, India, the US, North Korea, Turkey, and Vietnam. Significant progress has been made; REE deposits have been found all over the world. For example, Japan found a huge seabed REE deposit in the Pacific Ocean, and North Korea found a large REE deposit in northeastern Pyongyang. However, most of these deposits are not currently economically feasible.

Exploring new REE projects and reopening old REE mines is the most effective way to quickly produce new sources of REEs. If REE deposits all over the world were exploited, the global REE supply chain would become more stable.

\subsection{Recycling}

Recycling, also called "urban mining," is a very important source for many critical materials. Recycling REEs from primary ores, end-of-life consumer products, landfills, and scrap formed in rare earth oxides, metals, and material production are recognized as valuable ways to bring REE markets into balance (Binnemans et al. 2013; Binnemans and Jones 2015) and thus as positive and effective techniques for reducing the harmful environmental effects of REE mining. REE recycling has therefore received much attention from governments and businesses.

The US Critical Materials Institute was established to research REE reclamation, including the recovery of REEs from lamp phosphor dust and electronic waste, and to study the logistics and economics of rare earth remanufacturing and recovery. The Japan Oil, Gas and Metals National Corporation (JOGMEC) created a process for recovering used glass polishing agents as new products by developing several elemental technologies in 2012; it has also been working on REE recycling in recent years. China is actively pushing the development of REE waste recycling and smelting, and the separation processes of REE recycling enterprises were brought within the scope of Chinese policy management in 2016.

Most of the REEs used in consumer products can be recovered and reused. Recovering REEs from permanent magnets, nickel metal-hydride batteries, lamp phosphors, glass polishing powders, fluid cracking catalysts, and optical glass is viable; the recovery rate has reached 75 to $100 \%$ in lab-scale experiments (Binnemans et al. 2013). However, recycling technologies for REEs do not exist on a large industrial scale (Sun et al. 2015). Less than $1 \%$ of REEs are recycled from end-of-life products (UNEP 2011), which is nearly useless for the industry. However, due to the potential advantage of recycling, metal and electrical companies are working on recovering high-purity REEs from waste.

The most promising recycling material is fluorescent light bulbs. As, fluorescent light bulbs contain mercury, European consumers are required to recycle them; thus, REE recycling companies can obtain the materials easily. Belgium-based Solvay has already begun to extract six REEs from fluorescent bulbs and has recycled more than 1,000 tons of product. In Japan, REEs are being recovered on a limited scale, covering many fields of REE application, from consumer electronics and household appliances to hybrid cars. 
In 2013, Honda established the world's first process for reusing rare earth metals extracted from nickel-metal hydride batteries for hybrid vehicles.

REEs can be recovered from minerals other than end-of-life products. Rozelle (2016) reported that extracting REEs from US coal production by-products has proved technically feasible, with a recovery rate reaching $89 \%$ using deep eutectic solvent. The recovery of REEs from oil shale has been patented and protected under Chinese law. However, these methods have yet to be developed on an industrial scale.

Thus, recycling REEs from end-of-life consumer products and other minerals will provide a complement to REE resources and may also enhance the utility value of other minerals.

\subsection{Substitution}

For decades, research on REEs has focused on increasing their application performance due to their low prices. However, after China's export restriction, REE substitution became both attractive and essential to the global REE supply chain. There are two types of substitution: the replacement of one REE by another more abundant and cheaper REE in a given application and the replacement of REEs by non-REEs.

Sometimes it is easy to replace one REE, with another. In the example of permanent magnets, the more critical REE Sm can be replaced by the less critical REE Nd. Permanent magnets are divided into two categories: $\mathrm{NdFeB}$ magnets and SmCo magnets. SmCo magnets were invented in the 1970s; however, their commercial use has been hindered by an Sm shortage. Since 1985, SmCo magnets have been rapidly replaced by $\mathrm{NdFeB}$ magnets. Not only do NdFeB magnets have a higher density than SmCo magnets, but they are made with cheaper metal iron and Nd. Although Nd is also a rare earth element, it is more naturally abundant than is $\mathrm{Sm}$. Furthermore, SmCo magnets contain expensive metal cobalt.

By contrast, the second type of substitution developed rapidly after the supply disruption. For example in 2011, Japanese researchers built a motor for electric cars that does not require REEs. In March 2014, Hybrid Electric Vehicle Technologies (part of a team led by an organization subordinate to the US Department of Energy) also developed an REE-free electrical motor. LumiSands developed an alternative technology (silicon quantum dot phosphor) to replace REE phosphors in LED lights. At the same time, the rapid development of lithium-ion batteries has shown great potential to substitute for nickel-metal hydride batteries. However, this type of substitution is generally less efficient or problematic, and there is still a long way to go before large-scale commercial application is possible.

Several expensive and less abundant REEs such as $\mathrm{Eu}, \mathrm{Tb}$, and Dy are unlikely to be replaced at present. Eu is a critical REE for red lamp phosphors, which are essential inputs for the production of CFLs and LED screens (Binnemans and Jones 2015). Dy is essential for increasing the intrinsic coercivity of permanent magnets; it can im- 
prove resistance to magnetization at high temperatures, which is generally required for all permanent magnets used in generators or motors; the only substitute element for it is $\mathrm{Tb}$, but $\mathrm{Tb}$ is even rarer and more expensive (US DoE 2011). Tb is a very important material for the production of green fluorescence. There is no substitute for $\mathrm{Tb}$ as a lighting phosphor in fluorescent bulbs (US DoE 2011). There will be a significant deficit of these elements until new substitute technology is introduced to the markets, making the old technology based on REEs obsolete.

\subsection{Reducing REE content}

In contrast to REE substitution, significant progress has been made in reducing REE content in end-use products based on REEs, especially permanent magnets. It is possible to reduce the consumption of the more scarce element Dy in permanent magnets. In 2012, for example, Nissan developed a new electric motor that can reduce the use of Dy by $40 \%$ over conventional EV motors. Another Japanese firm, TDK, developed a method enabling it to manufacture magnets with up to $50 \%$ less Dy, while improving their residual flux density by up to $5 \%$. Furthermore, permanent magnets can be replaced by ferrite magnets however at the expense of poor performance.

Regarding efficient lighting, it is estimated that LEDs will quickly penetrate the lighting market in the near future due to their longer lifetime and higher efficiency compared to fluorescent bulbs. Moreover, LEDs contain only about $1 \%$ of the phosphors needed in fluorescent bulbs to offer equivalent lighting efficiency; thus, the phosphor demand for REEs will fall significantly, which means the HREE Eu could be in oversupply in the near future. However, it will take some time to develop large-scale commercial applications.

\section{Urgent problems}

\subsection{Environmental issues}

Many environmental issues are associated with REE production and recycling. The two main ones are radioactivity and pollutants.

Regarding radioactivity, nearly all REE deposits under exploration contain the radioactive elements thorium (Th) and uranium (U) and their decay products. The Bayan Obo deposit in China contains an average of about $0.04 \%$ Th and a little U. Xeotime in Malaysian placer deposits typically contains $2 \% \mathrm{U}$ and $0.7 \%$ Th (BGS 2010). Mountain Pass ore contains about $0.02 \%$ Th and $0.002 \%$ U. Generally, the content of Th is rather high. Nearly all of natural Th consists of the isotope $232 \mathrm{Th}$, a natural radioactive nuclide with a half-life of 14.05 billion years. Some countries are researching the use of Th as nuclear material in 
nuclear power plants, but Th has not been used on a large scale. Therefore, Th is usually considered radioactive waste, and REE producers must deal with it in compliance with local environmental regulations. Its disposal can be very expensive and complicated, increasing REE production costs. Radioactivity forced the Malaysian REE processing industry to fail and its plants to close; Rhone-Poulenc ceased REE production at its LaRochelle plant in 1994, and processing beach sands containing monazite have been banned in Australia, China, and Europe (BGS 2010).

Regarding pollutants, large amounts of chemical reagents are required in the production and recycling of REEs. For example, large amounts of chemical reagents such as sulphate, oxalate, ammonium bicarbonate, and extract solvent are widely used in the production of REO in Bayan Obo. As a result, large amounts of waste air, water, and residue are generated or discharged in the environment. This has caused widespread concern in China and partly explains China's export restrictions on REEs (MEP 2009; Wübbeke 2013). The recovery of REEs from end-of-life magnets and lamp phosphors will also require large amounts of chemical reagents such as sulphate and extract solvent, generating large amounts of waste water (Binnemans et al. 2013). After proper treatment, pollutants can usually be discharged to certainty standards or stored in tailings; however, this will undoubtedly increase costs of production. Furthermore, risks remain in the long run. For example, tailings usually consist of small particles with large surfaces, flotation chemicals, and waste residues. Generally, they are built on impoundment areas in the wild to ensure public safety. However, this is not a guarantee. Its surface materials could easily be washed away by rain or high winds. Storm water runs off during the rainy season, and the impoundment areas cannot store the huge amounts; as a result, the heavy metal and chemicals contained in tailings will pollute underground water and soil.

Radioactivity and pollutants are key environmental issues. If they cannot be properly addressed, REE production and recycling in many countries will be difficult and unacceptable, especially in Greenland, the European Union, and the US, given their high environmental standards.

\subsection{Unbalanced market}

Another important problem regarding the production and recycling of REEs should be considered: the unbalanced market. In global REE end-use applications, not all REEs have a market share equal to their proportion in REE ores. As shown in Table 2, the consumption of Ce represents $40.2 \%$ of global REE consumption, and $\mathrm{Tb}$ about $0.5 \%$. While $\mathrm{Ce}$ represents $43.2 \%$ of global REE deposits, Tb represents only $0.2 \%$ (see Table 1). The situation is even more complicated for specific REE deposits. For example, the Ce share in the Bayan Obo deposit is $50 \%$, while there is very little Tb, $\mathrm{Dy}, \mathrm{Ho}, \mathrm{Tm}, \mathrm{Yb}$, or Lu. HREEs are scarce relative to their end-use market demand because they are much less abundant than are LREEs in REEs ores, while there are surpluses of many LREEs. Thus, most new REE 
deposits, consisting mainly of LREEs, are not worth developing. Mountain Pass consists mainly of LREEs (e.g., La, Ce, Pr, Nd). It restarted production in 2012 but closed in 2015 due to softening LREE prices. Mt. Weld in Australia is also struggling to be profitable. Although the Bayan Obo deposit in China consists mainly of LREEs as well, its iron content is higher than its REE content, so it can produce iron at the same time (in fact, REEs used to be just a by-product of iron production). This gives Bayan Obo a production cost advantage over other deposits.

The unbalanced market could make REE recycling complicated. HREEs have more recycling value in the unbalanced market than do LREEs, making the recovery of REEs from polish powders, optical glass, and fluid cracking catalysts-which consist mainly of LREEs (mainly abundant La and Ce)-less attractive. However, though HREEs have a higher recycling value, their content in end-use products is usually very small. For example, NdFeB magnets generally consist of iron, $\mathrm{Nd}$, and boron; $\mathrm{Dy}$ can be used as an additive in high-performance magnets, which contain $30 \% \mathrm{Nd}$ and $5 \%$ Dy. In luminescent materials based on REEs, red phosphors consist of $4 \%$ to $8 \% \mathrm{Eu}_{2} \mathrm{O}_{3}$ and $92 \%$ to $96 \% \mathrm{Y}_{2} \mathrm{O}_{3}$ (Chen 2012). For a specific application, the figure could be very small. For instance, the weight for magnets in HEVs, plug-in hybrid electric vehicles (PHEVs), and AEVs is about 1 to $2 \mathrm{~kg}$ per vehicle (US DoE 2011), and the weight of Dy is about 50 to $100 \mathrm{~g}$ per vehicle. This means that it could be very expensive to recover Dy from HEVs, PHEVs, and AEVs-even beyond market prices.

\section{Conclusions and recommendations}

The importance of REEs for clean energy technologies is illustrated in this paper. Permanent magnets, high-efficiency lighting, fluid catalytic cracking, and other potential clean technologies such as magnetic refrigeration are important applications for REEs. However, an imbalance between REE supply and demand will occur, even though REEs are critical materials. Thus, ensuring the supply of REEs is critical to the development of clean energy industries in the long run. Possible solutions to this shortage include exploring new REE deposits, reopening old REE mines, seabed REE mining, recycling REEs from end-of-life products, using coal and coal by-products, performing substitution, and reducing critical REE content in end-use products. The supply problem can be mitigated or eliminated by combining these strategies. However, two related problems should be carefully considered and addressed: environmental issues and the unbalanced market. These two problems could influence the success or failure of REE production and recycling.

Solving the environmental problems requires assessing the environmental impact of REE production and recycling and conducting a long-term monitoring of REE production. To address the unbalanced market, developing new end-use applications based on excess REEs (e.g., La, Ce) and extending the applications that require excess REEs such as fluid cracking catalysts could mitigate the oversupply of some REEs, thereby raising REE prices and reducing the investment risk of REE production and recycling. These measures are not 
readily achievable without support from governments and REE companies as well as strong research and development.

This research received the financial support of the Fundamental Research Funds for Central Universities (FRF-TP-14-082A2).

\section{REFERENCES}

Alonso et al. 2012 - Alonso, E., Sherman, A. M., Wallington, T. J., Everson, M. P., Field, F. R., Roth, R. and Kirchain, R.E. 2012. Evaluating Rare Earth Element Availability: A Case with Revolutionary Demand from Clean Technologies. Environmental Science \& Technology 46(6), pp. 3406-3414.

BGS 2010. Rare Earth Elements. British Geological Survey.

BGS 2016. British Geological Survey Risk List 2015. British Geological Survey.

Binnemans, K. and Jones, P.T. 2015. Rare Earths and the Balance Problem. Journal of Sustainable Metallurgy 1(1), pp. $1-10$.

Binnemans et al. 2013 - Binnemans, K., Jones, P.T., Blanpain, B., Gerven, T.V., Yang, Y., Walton, A. and Buchert, M. 2013. Recycling of rare earths: a critical review. Journal of Cleaner Production 51(14), pp. 1-22.

Chen, Z. 2011. Global rare earth resources and scenarios of future rare earth industry. Journal of Rare Earths 29(1), pp. $1-6$.

Chen, Z., 2012. The impact of increasing rare earth raw material prices on new materials production costs. New Materials Industry 11, pp. 20-23 (in Chinese).

Du, X. and Graedel, T.E. 2011. Global Rare Earth In-Use Stocks in NdFeB Permanent Magnets. Journal of Industrial Ecology 15(6), pp. 836-843.

Dutta et al. 2016 - Dutta, T., Kim, K.H., Uchimiya, M., Kwon, E.E., Jeon, B.H., Deep, A. and Yun, S.T., 2016. Global demand for rare earth resources and strategies for green mining. Environmental Research 150, pp. 182-190.

EC 2014. Report on critical raw materials for the EU Report of the Ad hoc Working Group on defining critical raw materials. European Commission.

EC 2016. Report on critical raw materials for the EU Critical materials profiles. European Commission.

ERECON 2014. Strengthening the European rare earths supply chain: Challenges and policy options. Europe Commission.

Golev et al. 2014 - Golev, A., Scott, M., Erskine, P.D., Ali, S.H. and Ballantyne, G.R. 2014. Rare earths supply chains: Current status, constraints and opportunities. Resources Policy 41(41), pp. 52-59.

Gupta, C. K., Krishnamurthy, N., 2005. Extractive Metallurgy of Rare Earths, CRC Press, 508 pp.

Han et al. 2015 - Han, A., Ge, J. and Lei, Y. 2015. An adjustment in regulation policies and its effects on market supply: Game analysis for China's rare earths. Resources Policy 46(2), pp. 30-42.

Hurst, C. 2010. China's rare earth elements industry: What can the west learn? Institute for the Analysis of Global Security (IAGS).

Kanazawa, Y. and Kamitani, M. 2006. Rare earth minerals and resources in the world. Journal of Alloys and Compounds 408-412(19), pp. 1339-1343.

Kingsnorth, D. 2013. Rare earths: Is Supply Critical in 2013? [Online] Available at: http://investorintel.com/wp-content/uploads/2013/08/AusIMM-CMC-2013-DJK-Final-InvestorIntel.pdf [Accessed March 21, 2016].

Lynas, 2012. Lynas Corporation LTD: 2012 Annual Report. [Online] Available at: https://www.lynascorp.com/Pages/Reporting-centre-Annual-report.aspx [Accessed March 23, 2016].

Lynas, 2015. Mount Weld Mineral Resource and Ore Reserve Update 2015. [Online] Available at: https://www.lynascorp.com/Pages/Mt-Weld-Resources-and-Reserves.aspx [Accessed March 23, 2016].

Machacek et al. 2015 - Machacek, E., Richter, J. L., Habib, K. and Klossek, P., 2015. Recycling of rare earths from fluorescent lamps: Value analysis of closing-the-loop under demand and supply uncertainties. Resources Conservation \& Recycling 104, pp. 76-93. 
Mancheri, N.A. 2015. World trade in rare earths, Chinese export restrictions, and implications. Resources Policy 46, pp. $262-271$.

MEP 2009. The explanation of Compiling Standard of Pollutants from Rare Earth Industry. Ministry of Environmental Protection of the People's Republic of China (in Chinese).

Molycorp, 2013. Molycorp 2013 Annual Report. [Online] Available at: http://www.molycorp.com/ [Accessed March 23, 2016].

Rollat et al. 2016 - Rollat, A., Guyonnet, D., Planchon, M. and Tuduri, J., 2016. Prospective analysis of the flows of certain rare earths in Europe at the 2020 horizon. Waste Management 49, pp. 427-436.

Rozelle et al. 2016 - Rozelle, P.L., Khadilkar, A.B., Pulati, N., Soundarrajan, N., Klima, M.S., Mosser, M.M., Miller, C.E., Pisupati, S.V., 2016. A Study on Removal of Rare Earth Elements from U.S. Coal Byproducts by Ion Exchange. Metallurgical and Materials Transactions E 3(1), pp. 6-17.

SCIO 2012. Situation and Policies of China's Rare Earth. The State Council Information Office of the People's Republic of China.

Stegen, K.S. 2015. Heavy rare earths, permanent magnets, and renewable energies: An imminent crisis. Energy Policy 79, pp. 1-8.

Sun et al. 2015 - Sun, Z., Xiao, Y., Agterhuis, H., Sietsma, J. and Yang, Y., 2015. Recycling of metals from urban mines - a strategic evaluation. Journal of Cleaner Production 112, pp. 2977-2987.

Tukker, A. 2014. Rare earth elements supply restrictions: market failures, not scarcity, hamper their current use in high-tech applications. Environmental Science \& Technology 48(17), pp. 9973-9974.

UNCTAD 2014. Commodities at a glance, Special issue on rare earths. United Nations Conference on Trade and Development.

UNEP 2011. Metal Recycling: Opportunities, Limits, Infrastructure. United Nations Environment Programme.

US DoE 2011. Critical Materials Strategy. U.S. Department of Energy.

USGS 2010. Mineral commodity summaries (Rare Earth). U.S. Geological Survey.

USGS 2014a. The rare-earth elements - Vital to modern technologies and lifestyles. U.S. Geological Survey.

USGS 2014b. Historical Statistics for Mineral and Material Commodities in the United State. U.S. Geological Survey.

USGS 2016. Mineral Commodity Summaries (Rare Earth). U.S. Geological Survey.

Wilburn, D.R. 2012. Byproduct Metals and Rare-Earth Elements Used in the Production of Light-Emitting Diodes Overview of Principal Sources of Supply and Material Requirements for Selected Markets. U.S. Geological Survey.

Wübbeke, J. 2013. Rare earth elements in China: Policies and narratives of reinventing an industry. Resources Policy 38(3), pp. 384-394.

Zhang et al. 2015 - Zhang, L., Guo, Q., Zhang, J., Huang, Y. and Xiong, T. 2015. Did China's rare earth export policies work? - Empirical evidence from USA and Japan. Resources Policy 43, pp. 82-90.

DOSTAWY PIERWIASTKÓW ZIEM RZADKICH (REE) A CZYSTE TECHNOLOGIE ENERGETYCZNE: NOWE PROBLEMY DO ROZWIĄZANIA

\section{Słowa kluczowe}

pierwiastki ziem rzadkich, czyste technologie energetyczne, łańcuch dostaw

\section{Streszczenie}

Pierwiastki ziem rzadkich (Rare Earths Elements) mają istotne znaczenie dla rozwoju czystych technologii energetycznych, takich jak turbiny wiatrowe czy pojazdy hybrydowe. Światowy popyt na REE będzie wzrastał w związku z globalną transformacją w kierunku bardziej czystej (ekologicznej) 
gospodarki w okresie najbliższych dziesięcioleci. Wysoki popyt wymagać będzie stabilnego łańcucha dostaw REE w dłuższej perspektywie. Chiny mają monopol w zakresie globalnej produkcji i wydobycia REE. Światowe dostawy REE obarczone są jednak ryzykiem zakłóceń wynikających z chińskiej polityki w tym zakresie. W związku z tym, powinny być przyjęte nowe środki i strategie w celu zaspokojenia przyszłego popytu/podaży na REE. Istnieje pilna konieczność: poszukiwania nowych złóż, opracowania skutecznych technik recyklingu z wycofanych z eksploatacji produktów, poprawy technologii z zastosowaniem substytutów REE oraz zmniejszenie liczby krytycznych pierwiastków ziem rzadkich w stosowanych urządzeniach. Działania te stanowią poważne wyzwanie ze względu na czynniki środowiskowe i niezrównoważony rynek (monopol podaży). Przezwyciężenie ich wymaga odpowiednich działań ze strony rządu i firm zajmujących się produkcją REE.

\title{
RARE EARTH ELEMENTS SUPPLY VS. CLEAN ENERGY TECHNOLOGIES: NEW PROBLEMS TO SOLVE
}

\author{
Keywords \\ rare earth element, clean energy technology, supply chain
}

\section{Abstract}

Rare earth elements (REEs) provide important properties to clean energy technologies such as wind turbine and hybrid electric vehicles. The global REE demand will grow rapidly during the global transformation toward a greener economy in the next decades. This high demand will require a steady supply chain in the long run. China has a monopoly of global REE production and extraction. The global REE supply chain runs the risk of disruption along with Chinese REE policy evolution. To overcome this supply chain vulnerability, new strategies and measures should be adopted to satisfy future REE supply/demand. There is a pressing need to explore REE deposits, develop efficient REE recycling techniques from end-of-life products, improve substitution technologies for REEs, and reduce the number of critical REEs used in devices. Such measures are facing significant challenges due to environmental factors and an unbalanced market, and overcoming them requires efforts from government and REE companies. 